\title{
The Implication of Global Economic Recession on Sustainable Housing in Lagos Megacity
}

\author{
ADEBAMOWO, Michael Adeloye \\ Senior Lecturer \\ Department of Architecture \\ University of Lagos, Akoka, Lagos, Nigeria \\ Tel: 234-802-324-7061 E-mail:- adebamowomichael@yahoo.com
}

\begin{abstract}
This paper is a contribution to the pertinent discourse on the issue of global economic recession as it affects sustainable housing using the Lagos megacity as a case study. A global structural defect in the economy will eventually affect all the aspects of our lives and existence and as such must be studied, the effects understood and the likely impact on the environment particularly in the aspect of Sustainable Housing development be examined.

In order to do this, a survey of 60 key players in the housing industry was conducted to examine the impact of the recession on sustainable housing and findings showed that the impact of the recession on house prices is significant but not severely great as there are still opportunities to be explored.

Finally the paper is divided into five sections. The first section is the introduction while the second section is an overview of sustainable housing development and emergence of megacities; with the third section discussing the Lagos Megacity and the state of housing. The survey conducted with results and discussion is presented in the fourth section and the paper concludes in the fifth section with the recommendation of strategies to mitigate the effect of the recession on sustainable housing.
\end{abstract}

Keywords: Global economic recession, Sustainable housing and Lagos Megacity

\section{Introduction}

\section{Global Economic Recession: Its causes:}

A recession is usually characterized by a state of negative economic growth spanning up to two consecutive financial quarters. The global financial crisis of 2008 is a major financial crisis the worst of its kind since the Oreat Depression of 1930 (Pells, 2008). This became prominently visible in September 2008 with the failure, merger of several large US- based financial firms. Beginning with failures of large financial institutions in the United States, it rapidly evolved into a global crisis resulting in a number of European bank failures, declines in various stock indexes, and large reductions in the market value of equities and commodities worldwide. The crisis has led to a liquidity problem and the de-leveraging of financial institutions especially in the USA and Europe, which further accelerated the liquidity crisis. The stock markets have fallen around the world, large financial institutions have collapsed or have been bought out and governments in even the wealthiest nations have had to come up with rescue packages to bail out their financial systems.

According to Oyesiku, 2009, economic recession doesn't just occur; certain factors which include dollar collapse, oil price rise, inflation, housing bubble, loss of consumer confidence, excess buying and global economy are responsible. This current global financial meltdown which began with the US housing bubble in 2006 was aggravated by low interest rates and increased global liquidity. The subprime or near-subprime loans being initiated and sold to banks by the US real estate brokers, as well as the hedge funds, the Structured Investment Vehicles (SIV) and financial instruments such as Collateralized Debt Obligations (CDO), Credit Default Swaps (CDS) and other derivatives were the bane of the crisis. Other factors included the under estimation of the liquidity risk and the employment of short-term oriented incentive schemes. A combination of these factors imposed deleterious effects on the US financial system, which in turn, got translated into the global economy, owing to the wrong decision by the US Government not to intervene at a most crucial time.

In view of this, much of the global economic crisis is traceable to inefficient regulation of financial actors as well as the needless post-crisis foot-dragging in Government intervention, which made the meltdown that could have been limited to the US economy, to snowball into a global financial dilemma. The far-reaching implication of this US-induced economic quagmire is manifest in a host of recession symptoms, which have already spread not only to other developed economies of the world but also to emerging or transition economies. 


\section{Global Economic Recession:- effect at global level.}

In Euro zone, Ireland was the first country that faced a sudden rupture in its real estate sector after decades of a steady financial boom. The prices of houses in Ireland fell eighteen straight months in a row, contracting the economy by $0.5 \%$ in the second quarter of 2008 following an earlier decline of $0.3 \%$ witnessed in the first quarter. The status of the real estate sector as the mainstay of Irish economy prompted a major growth slide in 25years, in the light of the ensuring recession.

France GDP dropped by $0.1 \%$ in the third and fourth quarter of 2008 after a staggering $0.3 \%$ in the second quarter. The recession panic in France is more reinforced by the growing unemployment (about 7.4\%), inflating oil prices, declining exports and the reality of global credit crunch. Other countries currently in recession or at the brink of such include Sweden, Estonia, Latria, Finland, Netherlands, and Iceland. In the Euro zone as a whole, economic growth declined by $0.2 \%$ in the second quarter of 2008 after a paltry $0.7 \%$ growth in first quarter. Industrial Output is already falling at an alarming pace, unemployment is increasing while consumer confidence is fast eroding.

Canada, which is the second leading economy in the North American region experienced a $0.8 \%$ contraction in the first quarter of 2008 while a revised statistics showed a GDP growth of $0.3 \%$ in the second quarter. Canada's economy was slowed down by a production decline in its key sectors such as mining, oil and gas, construction and automobile.

In Asia, Japan experienced negative growth in the second quarter of 2008 with a decline of $0.7 \%$ on the quarter-on-quarter and 3\%, year-on-year basis respectively; and this came after a staggering growth of $0.8 \%$ on quarter-on-quarter and 3.3\% year-on-year basis in the first quarter of the year. Presently the global financial crisis has reduced the demand for the country's products both at home and international market levels.

China's growth also slowed down year-on-year in the first quarter of 2008, from $11.7 \%$ to $10.6 \%$. This was followed by a further decline in the second quarter to $10.1 \%$ owing to sluggish earnings from exports and tight macro-economic policies. In the second quarter of 2008, trade surplus dropped by $12 \%$ year-on-year to $\$ 58$ billion, mainly as a result of a plunge in demand from the United States.

In the developed economics, the consumer prices for energy were up to $20.9 \%$ year-on-year in August, 2008 while those for food also increased by $7.1 \%$. In the United States for instance, Consumer Price Index (CPI) rose up by 5.4\% year-on-year in August; $2.1 \%$ in Japan; $4.7 \%$ in the United Kingdom; $4.1 \%$ in Italy; 3.5\% in Canada; 3.2\% in France; and $3.1 \%$ in Germany.

Another important negative implication of the global economic crisis in the financial sector is the worsening spate of interest rate cuts. Apart from this, the world has also witnessed a major crash landing in the stock markets. In September 2008, a Wall Street despair that was informed by growing incidence of bank failures and heightened by the US congress vote for the proposed $\$ 700$ billion bail out plan, culminated in one of the biggest sell-offs of stocks in financial history, which led to a remarkable market loss of over $\$ 1$ trillion in Just few hours. In the United Kingdom, another major market panic of the United State's magnitude led to a 9\% drop in the United Kingdom's FTSE 100 index, this was followed by an intra-day drop of about 5\% in the US Dow Jones; 7.7\% drop in France CAC index and $8.4 \%$ loss in Germany Dax.

The credit crunch in the stock market became further exacerbated by the refusals of banks to lend to each other. Depositors in response to the rising trend of banks' distress are holding on to their monies while panic withdrawal is prevalent in all the major economies. Thus the banking sector became unable to perform their traditional services of intermediation- taking from those with excess and lending to those with deficits.

\section{Global Economic Recession:- effect at National level.}

The World Bank President, Robert Zoellizk opined that "the event of September 2008 could be a tipping point for many developing countries. A drop in exports, as well as capital inflow, will trigger a fall out in investments. Deceleration of growth and deteriorating financing conditions, combined with monetary tightening will trigger business failures and possibly banking emergencies. Some Countries will slip toward balance of payment crises. As it is always the case, the most poor are the most defenseless". Truly this statement of the World Bank president underscores the grave implication of economic globalization on the economics of third world countries and transition economics such as Nigeria.

In the World Bank report on "Global Development Finance 2009", it was stated that because of the financial-market fragility, net private capital inflows, remittance inflows from migrants and investment inflows to developing countries including Nigeria had continued to decline. The bank said that Net private capital inflow to developing countries fell to \$707billion in 2008, a sharp drop from a peak of \$1.2trillion in 2007 and that it was also projected to fall further in 2009 to $\$ 363$ billion. For remittance inflow, the group painted a gloomy picture listing Nigeria as 
the biggest beneficiary of remittance inflow from its large army of populace in the Diaspora among those to be mostly affected.

Nigeria, the largest country in Africa, according to the report, has about $9 \%$ of its population outside the country, with the United Kingdom being its major source of remittance inflow. Though official figures are not available, economists and financial analysts believe that remittances from Nigerians in various parts of the world now exceed \$1billion annually, ranking second only to oil exports as a source of foreign exchange earnings.

The report also revealed that even though Africa is the least integrated with the global economy, it may be the worst hit region by the global economic crisis. Each of the four channels through which the crisis is affecting Africa has a particularly nefarious impact. Private capital flows, which in 2007 had surged to \$53billion for the first time exceeding foreign aid to the continent are declining. Since last year, African stock markets have fallen by an average of $40 \%$ with Nigeria falling by an average of over $60 \%$.

Finally Nigerian economy has been hit hard by reduced external demand, plunging oil price, weaker remittance, tourism revenues and sharply lower capital flows.

\section{Overview of Sustainable Development and Emergence of Megacities}

Following world conferences on the environment held in Stockholm in 1972, Rio de Janeiro in 1992 and Istanbul in 1996, there has been greater concern for global development process to seek for integration of exploitation of resources and economic growth and physical development. The need to improve the quality of life of city inhabitants through their production and consumption activities without compromising the ability of future generations to meet their economic, social, cultural, health and political needs remains the focus of sustainable development (Satterthwaite, 1999).

The concept of sustainable development was popularized as a normative goal by the world Commission on Environment and Development in its 1987 report. This Brundtland Commission defines sustainable development as a development that meets the needs of the present without compromising the ability of future generations to meet their own needs. This definition suggests the need to balance two concerns, one having to do with present, or intra-generational needs and the other having to do with future, or inter-generational needs. Meeting today's needs without diminishing the capacity of future generations to meet their own is the main challenge of sustainable development which stands on three pillars: viz:- Economic, Social and Environmental.

Sustainable development is also viewed in respect to what it specifically seeks to achieve. To illustrate, it is helpful to examine three set of goals that use different time - horizons: the short-term (2015) goals of the millennium declaration of the United Nations; the two-generation goals (2050) of the sustainability transition of the board on Sustainable Development; and the long-term (beyond 2050) goals of the Great Transition of the Global Scenario Group.

Drakakis - Smith (1995) review of third world cities offers some insight into the complexity and challenges facing third world city sustainability. The study suggests some reasons why sustainable development may be seen as a foreign concept in third world countries and how third world governments have continued to see these problems as secondary to other concerns such as economic growth and politics.

Satterthwaite (1999) discusses key issues on how cities can be made compatible with sustainable development goals with emphasis on both the potential advantages of cities for the achievement of sustainable development goals and the extent to which good governance is central to realizing this objective. According to Newman and Kenworthy 2003, sustainability adopts the metaphor of metabolism to human settlements: a city can be defined as becoming more sustainable if it is reducing its resource inputs (land, energy, water and materials) and waste outputs (air, liquid and solid waste) while simultaneously improving its livability (health, employment, income, housing, leisure activities, public spaces and community).

Cities in the developing world in general face major urban challenges, not least because global economic restructuring has decimated social opportunities and prosperity for many citizens. The overall situation of megacities in developing countries is characterized by a conflicting mixture of excessive poverty and wealth; severe unemployment and great economic opportunities. In the case of Nigeria, fuelled by the oil-boom of the 70s, the enduring by-products of rapid urbanization include: slums, overcrowding, poor sanitation, air and water pollution, clogged sewers, solid waste contamination, 'wicked' urban traffic, illegal conversion of land-use, inadequate housing, mass unemployment, insecurity, rising crime wave and Niger-Delta problems.

\section{The Lagos Megacity and State of Housing}

A megacity by definition is a city or a continuous urbanized area with population of at least 10million people (UNCHS, 1996). Table 1 is a composite of four lists showing the world's megacities in 1992, 1995, and 2007, with a projection for 2015 . 
Lagos is considered to be one of the most rapidly urbanizing metropolitan areas in the world, indeed the most populous conurbation in Nigeria. With a population of only 126,000 in 1931, 290,000 in 1950, currently about 18 million and projected to be the third largest megacity in the world with a population of about 25 million in 2015 (UNCHS, 1996).

The Lagos Megacity which covers an area of 153,540 hectares (Presidential Committee, 2006) emerged out of a two-pronged realization:- first is the projection that Lagos could become the third largest megacity in the world by 2015; second is the fact that the city had suffered severe infrastructure neglect for many decades. Urban growth has occurred so quickly and in the absence of proper and proactive planning to guide the hyper-growth. The Megacity Project is therefore conceived as the re-development of Lagos to fit its new urban status.

The Lagos State Government has been engaged in a passionate drive to attract investors from all over the world to come and participate in the Lagos Megacity Project stressing on the vast opportunities to be opened up for prospective investors despite the current global economic recession in such identified areas as transportation, roads, waste management, provision of water, power, tourism, property development and establishment of bus assembly plants. The main features of this development are:-

- Construction of new roads and a light rail road system.

- Development of water routes to facilitate marine transportation.

- Construction of a fourth mainland bridge.

- Beautification and landscaping of high ways and recreational parks.

- Construction of 10,000 housing units in the Lekki Peninsula.

- Re-construction and expansion of the Lagos-Badagry expressway into a 10-lane conduit with a light rail, serving as a trans-regional route linking Nigeria to the neighbouring Republics of Benin, Togo and Ghana which are expected to extend the road across their various borders.

- Construction of a Ring Road to link all the 28 activity centres in the states.

- Construction of a water-way and the proposed Eco. Atlantic City on the Badagry water front "the New City on the Atlantic", a PPP Venture envisioned as a fully integrated business hub. This is to be a planned district constructed on reclaimed land, targeting 250,000 residents and 200,000 commuters flowing daily to the Island and powered by an off-grid 130 Megawatts Electric Plant (Lagos Energy City, 2007).

Given the constraints of time and space, however one key aspect worthy of particular attention is housing.

\section{Housing in the Lagos Mega-City}

Housing in Lagos is grossly inadequate both quantitatively and qualitatively. In 1976, it was estimated that 111,000 residential buildings were available in Lagos to provide accommodation for 3.2million people, which is an average of 28.8 persons per building. By 1980, the occupancy rate has grown worse to about 30 persons per building. It was further estimated that only $2 \%$ of the existing population are accommodated in self-contained buildings with $98 \%$ living in "rooming" type of houses.

Presently the Nation's current housing deficit is estimated as 17 million units and it has been projected that Lagos Metropolis would require about 40,000 housing units yearly estimated at \$1billion yearly to accommodate its rising population.

In response to this problem, in 2008, the ministry of housing delivered over 1,000 housing units in seven locations across the state. Government is also adopting the strategy of public-private partnership to meet the housing needs. In this respect, 27 developers have proposed the construction of 20,000 housing units in 10 different locations across the state. Under this arrangement the government will provide the land as equity while private resources would be deployed to construct the estates.

And both the government and the private are going about this with little or no attention to sustainability. According to Edwards (2005), sustainable housing may be defined as "housing that creates sustainable communities in a resource-efficient manner". The resources referred to are energy, water, land, materials and human labour. Sustainable housing projects therefore need to be:-

- Energy efficient;

- Efficient in the use of other resources, especially water;

- Designed to create robust, self-sustaining mixed-use communities;

- Designed for long life; 
- Designed for flexibility in lifestyle and tenure;

- Designed to maximize recycling;

- Healthy and

- Designed to embrace ecological principles.

Sustainable housing is more than an exercise in physical attributes. It will be judged a success only if it leads to economic prosperity, stimulates social cohesion, provides security, supports social welfare and is designed to enhance personal community and global health. Sustainable housing therefore brings together environmental, social, economic, cultural and political dimensions into a single agenda.

\section{Methodology}

The study was based on a questionnaire addressed to the key players in the housing sector in Lagos. These key players include the real estate developers (private \& public), Mortgage bankers/providers, real estate financial institution, construction firms and building consultants (Architects, Engineers, Planners, Quantity Surveyors and Estate Surveyors).

A total of 60 respondents were involved in this survey, out of which 35 were from the construction sectors and 25 from financial sectors. Due to the constraints of time and space only the CEO's and MDs in these selected organizations are targeted. Their personal opinions on the following issues were sought for:-

- The state of housing in Lagos.

- The practice of sustainable housing design and development.

- The identification of the factors affecting the delivery of housing in Lagos.

- The performance of the housing market over the past 3 years.

- The impact of economic crunch on house prices in Lagos.

In a scale of 0 to 5 ( 0 very poor, 1 poor, 2 fair, 3 good, 4 very good and 5 excellent) the respondents' average for the state of housing in Lagos is around 1.2, (fig. 1) which could be generally described as poor. Most of the respondents agreed that the acute shortage in housing especially among the low income group is responsible for this couple with the lack of basic amenities in such houses. However, the few who rated the state of housing as being fair or good based their conviction on the sprawl of housing development in the high brow areas of Ikoyi, Victoria Island, Lekki and Ikeja which are quite few. It was also noted that most housing developers build for the upper class and the rich since they want quick returns on their investments. Moreover construction cost is so high that the products have become unaffordable and unattractive to the middle and lower classes.

With regards to the practice of sustainable housing design and development; majority of the respondents viewed the concept of sustainability as foreign probably because of lack of understanding on one hand and the resolve to address the more pressing needs of quantity and amenities on the other hand (fig. 2).

In the identification of factors affecting housing delivery in Lagos; the respondents ranked the factors in the following order of importance:-

Access to Land: The problem of high cost of land, difficulty in obtaining title papers and building Plan Approval.

Provision of Infrastructure:- Lack of good roads, drainage and electricity. Cost of providing these basic infrastructures has made housing unaffordable in Lagos.

Access to finance: Interest rates are as high as $27 \%$, lending conditions are stringent and unfavourable coupled with the global economic crisis.

Shortage and high cost of building materials

Shortage of skilled labour: There is an acute shortage of artisans in the construction industry. This is probably due to the unwillingness of our youth to learn trades like carpentary, welding masonary etc preferring to sell recharge cards, ride 'okada' (motorcycles used for transportation) and get rich quick by 'yahoo yahoo! (the 419 scams).

With regards to the performance of the housing market, most of the respondents agreed that the market over the past couple of years have seen an unprecedented growth with the value of properties in some areas like Lekki and Ikoyi appreciating by over $75 \%$ annually. However this upward trend reached its peak around March 2008 following the crash of the Nigerian stock market. Thereafter the global economic recession became manifest around December 2008 and that compounded the problem. Right now prices have remained stagnant for a while and even gone down in some areas in Ikoyi with the hardest hit being the expensive prime properties that have become less attractive in 
view of the credit crunch which has reduced the capacity to afford such properties. However it is important to mention that the low income housing market has not suffered to this extent, in fact in most areas of low income housing, rent has gone up. This is essentially due to the fact that we already have acute housing shortage in this category (fig. 3).

As for the impact of global economic recession on sustainable housing; the respondents' average in a scale of 0 to 5 (0, no impact, 1 small impact, 2 moderate impact, 3 significant impact, 4 great impact, 5 severe impact) is 3.1 (fig. 1) which means that the impact is significant.

According to the respondents, some of the effects of the economic downturn on housing include the following:-

- Banks no longer give long-term loan, now limited to less than 10years with high interest rates $(22-27 \%)$.

- Purchasing power has reduced leaving many completed properties unsold or unoccupied even though demand is still evident.

- High cost of building materials and components.

- Compromise in the quality of housing and further shortage in supply.

- Upward inflationary trend especially on imported materials.

- Unabated energy problem with high cost of transportation.

- Dearth of skilled labour.

- High rate of unemployment, retrenchment and cut down on salaries.

- Low returns on Building Investments.

- Poor infrastructural provisions.

Despite the above, the respondents generally agree that the impact of economic recession on housing in Lagos, though significant, could have been worse but for the ever increasing population coupled with acute shortage in housing and for areas like Victoria Island and Ikoyi, the Niger Delta crisis has caused many expatriates to relocate from the region to these parts of Lagos.

\section{Conclusion}

The general discussion on the concept of sustainable housing and its relationship to the present global economic recession, no doubt have effects that are imminent. Though as Lagarde (2006) points out "the formats of strategies and process for achieving sustainable development (which is conducive for sustainable communities) reflect varying degrees of understanding and differing perspectives. Such an understanding could ultimately define a country's successes, most practices in many developing countries are not sustainable".

With the recession, the rate of job loss becomes far too alarming as many businesses across all sectors suffers a serious decline in sales turnover and their profits shrink, borrowers default on repayment of loans, banking system breaks down, prices of food, fuel and other essential commodities shoot up, value of houses drops, and companies offer voluntary retirement programs to reduce their workforce and cut down wages.

Perhaps the most critical of the symptoms of global economic recession are negative economic growth and growing unemployment. The implication of negative economic growth include falling prices of homes, and other products, and generally a slowdown of the economy due to a fall in production which also is as a result of a weakened demand. Therefore a fall in demand of a major product would lead to inefficient process, not only in production but also in the output. There is the likelihood of inappropriate use of the environment because technology will not be channelled to improve the use of resources, and consequently the rudimentary way or old unsustainable ways of production will be fallen back upon (Oyesiku, 2009). In effect, global economic recession will not only make the environment unsustainable but also lead to a rethinking of the concept of sustainability itself, since Seers (1989) Todaro (1989) and Mabogunje (1980) considered unemployment as fundamental focus of development, one can then expect the development trend to be getting worse and inequality to get wider. Not only this, the Millennium Development Goals will be difficult to achieve as development will witness high cost of environmental problems.

Nevertheless, when the concept of sustainability is well imbibed by all stakeholders in housing it would help to mitigate the effect of this current global economic recession. In the sense that there would be lower construction and maintenance costs by avoiding air conditioning and artificial lighting for example. Also better indoor thermal comfort and improved health condition in housing would be achieved. This would definitely bring about improved rental income through better image for the building with improved flexibility and adaptability to meet future needs. 
There are a number of strategies that can be implemented to help an economy to move out of a recession. The strategy adopted and applied varies and depends on the type of economic system and analysis followed by the country's policy makers. For instance Lagos state government adopts a strategy of strengthening its financial base through improved internally generated revenue and capital re-mobilization, the adoption of a well disciplined and people centered budgetary policy as well as the consistent and strategic partnership with the private sector.

\section{References}

Pells L. David. (2008). Silver living:- why the economic recession may be good for project management. Pm world today, vol. 10, issue 7.

Oyesiku. (2009). Global Economic Recession, the Environment and Sustainable Development in Nigeria. Annual Lecture Series, College of Management and Social Sciences, Osun State University, Oshogbo held on $28^{\text {th }}$ April, 2009.

World Bank Report on Global Development Finance (2009) - Punch Newspaper.

Satterthwaite D. (1999). (ed.) The Earthscan Reader in Sustainable Cities, London: Earthscan publications, London.

Drakakis - Smith D. (1995). Third world cities: Sustainable Urban Development, 1 Urban Studies, vol. 32 nos 4 \& 5, pp $659-677$.

Newman P. and Kenworthy J. (2003). Sustainability and Cities: Summary and Conclusions, in AIR Cuthbert (ed.). Designing Cities: Critical Readings in Urban Design. Oxford: Blackwell, pp 235 - 242.

UNCHS. (1996). An Urbanizing World:- Global Report on Human Settlements. Oxford University Press, Oxford.

World Commission on Environment and Development (1987) - Our common future; Oxford University Press, Oxford.

Federal Republic of Nigeria. (2006). Report of the Presidential Committee on Redevelopment of Lagos Megacity Region.

Lagos Energy City. (2007). Lagos Energy City Real Estate and Property Investment, Nigeria. (http://www.lagosenergycity.com.80/default.aspx?tabid=765). Accessed on $8^{\text {th }}$ April, 2009.

Edwards, B. (2005). Rough Guide to Sustainability, RIBA Enterprises London pp 3 - 52.

Lagarde, M. (2006). 'Mainstreaming Sustainable Development: Evolving Perspectives and Challenges from the Philippine Experience'. National Resources Forum 30. 
Table 1. Megacities of the World 1992, 1995, 2015.

\begin{tabular}{|c|c|c|c|c|c|c|c|c|c|c|}
\hline $\begin{array}{l}\text { Urban } \\
\text { Agglomeration }\end{array}$ & $\begin{array}{l}\text { Popl. } \\
\text { 000s }\end{array}$ & Rank & $\begin{array}{l}\text { Popl. } \\
\text { 000s }\end{array}$ & Rank & $\begin{array}{l}\text { Popl. } \\
\text { 000s }\end{array}$ & Rank & $\begin{array}{l}\text { Popl. } \\
\text { Proj. } \\
\text { 000s }\end{array}$ & Rank & $\begin{array}{l}\text { Popl. } \\
\text { Proj. } \\
\text { 000s }\end{array}$ & Rank \\
\hline & 1992* & & $1995 * *$ & & $2007 * * *$ & & $2015 * *$ & & $2025 * * *$ & \\
\hline \multicolumn{11}{|l|}{ Africa } \\
\hline Lagos & & & 10,287 & 15 & & & 24,437 & 3 & 15,796 & 12 \\
\hline Cairo & & & 9,656 & 19 & 11,893 & 15 & 14,494 & 16 & 15,561 & 13 \\
\hline Kinshasa & & & & & & & & & 16,762 & 11 \\
\hline \multicolumn{11}{|l|}{ Asia } \\
\hline Tokyo & 25,772 & 1 & 26,836 & 1 & 35,676 & 1 & 28,701 & 1 & 36,400 & 1 \\
\hline $\begin{array}{l}\text { Bombay } \\
\text { (Mumbai) }\end{array}$ & 13,322 & 6 & 15,093 & 5 & 18,978 & 5 & 27,373 & 2 & 26,385 & 2 \\
\hline Shangai & 14,503 & 5 & 15,082 & 6 & 14,987 & 7 & 23,382 & 4 & 19,412 & 9 \\
\hline Jakarta & & & 11,500 & 11 & & & 21,170 & 5 & 12,363 & 19 \\
\hline Karachi & & & 9,863 & 18 & 12,130 & 12 & 20,616 & 7 & 19,095 & 10 \\
\hline Beijing & 11,433 & 10 & 12,362 & 8 & 11,106 & 16 & 19,432 & 8 & 14,545 & 15 \\
\hline Dacca & & & 7,832 & 22 & 13,485 & 9 & 18,964 & 9 & 22,015 & 4 \\
\hline $\begin{array}{l}\text { Calcutta } \\
\text { (Kolkata) }\end{array}$ & 11,106 & 12 & 11,673 & 9 & 14,787 & 8 & 17,621 & 12 & 20,560 & 8 \\
\hline Delhi & & & 9,882 & 17 & 15,926 & 6 & 17,553 & 13 & 22,498 & 3 \\
\hline Tianjin & & & 10,687 & 13 & & & 16,998 & 14 & & \\
\hline Metro Manila & & & 9,280 & 21 & 11,100 & 17 & 14,711 & 15 & & \\
\hline - Seoul & 11,589 & 9 & 11,641 & 10 & & & 13,139 & 18 & 14,808 & 14 \\
\hline Istanbul & & & 9,316 & 20 & 10,452 & 19 & 12,345 & 20 & 12,102 & 20 \\
\hline Lahore & & & 5,085 & 27 & & & 10,767 & 22 & 10,512 & 24 \\
\hline Hyderabad & & & 5,343 & 26 & & & 10,663 & 23 & & \\
\hline Osaka & 10,535 & 13 & 10,601 & 14 & 11,294 & 14 & 10,601 & 24 & 11,368 & 22 \\
\hline Bangkok & & & 6,566 & 25 & & & 10,557 & 25 & & \\
\hline Teheran & & & 6,830 & 24 & & & 10,211 & 26 & & \\
\hline Moscow & & & & & 10,452 & 18 & & & 10,526 & 23 \\
\hline Guangzhou & & & & & & & & & 11,835 & 24 \\
\hline Shenzhen & & & & & & & & & 10,196 & 25 \\
\hline $\begin{array}{l}\text { Chennai } \\
\text { (madras) }\end{array}$ & & & & & & & & & 10,129 & 26 \\
\hline \multicolumn{11}{|l|}{ South America } \\
\hline Sao Paolo & 19,235 & 2 & 16,147 & 2 & 18,845 & 4 & 20,783 & 6 & 21,428 & 5 \\
\hline Mexico City & 15,276 & 4 & 15,643 & 4 & 19,028 & 3 & 18,786 & 10 & 21,009 & 6 \\
\hline Buenos Aires & 11,753 & 8 & 10,990 & 12 & 12,795 & 10 & 12,376 & 19 & 13,768 & 16 \\
\hline Rio De Janeiro & 11,257 & 11 & 9,888 & 16 & 11,748 & 13 & 11,534 & 21 & 13,413 & 18 \\
\hline Lima & & & 7,452 & 23 & & & 10,554 & 25 & & \\
\hline \multicolumn{11}{|l|}{ North America } \\
\hline New York & 16,158 & 3 & 16,329 & 3 & 19,040 & 2 & 17,636 & 11 & 20,628 & 7 \\
\hline Los Angeles & 11,853 & 7 & 12,410 & 7 & 12,500 & 11 & 14,274 & 17 & 13,672 & 17 \\
\hline
\end{tabular}

*Source: Castells (1996), p.404 Worlds Larges: Urban Agglomerations

**Source: UNCHS (1996), PP 451-456

***Source: UN-HABITAT (2008) The Worlds Megacities, 2007 and 2025 (Data from UN

Population Division, World Urbanization Prospects: The 2007 (Revision) 


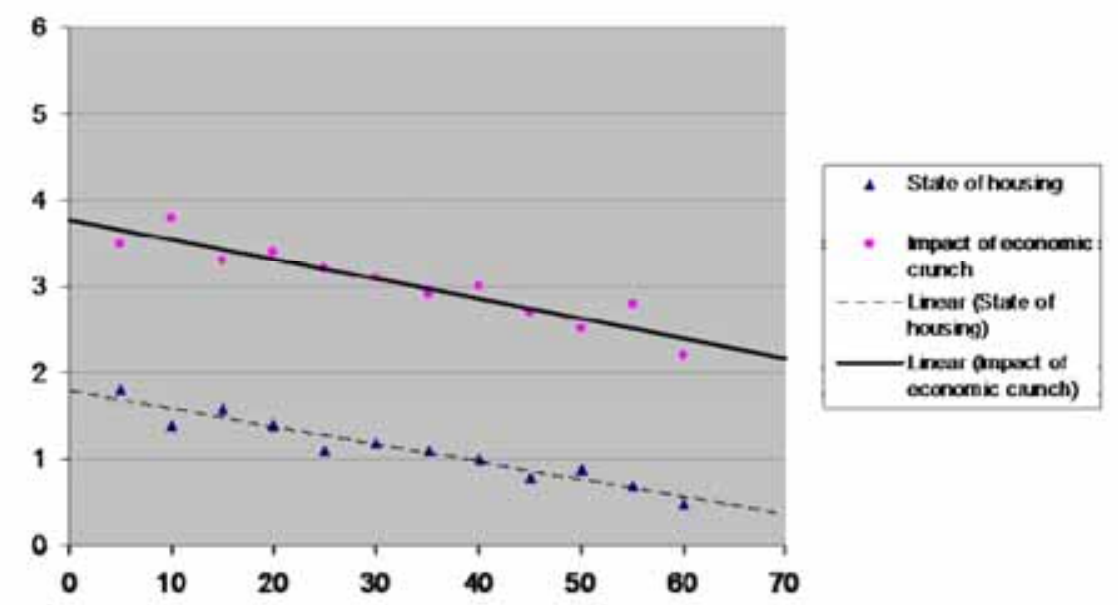

Figure 1. State of housing/impact of economic crunch vote

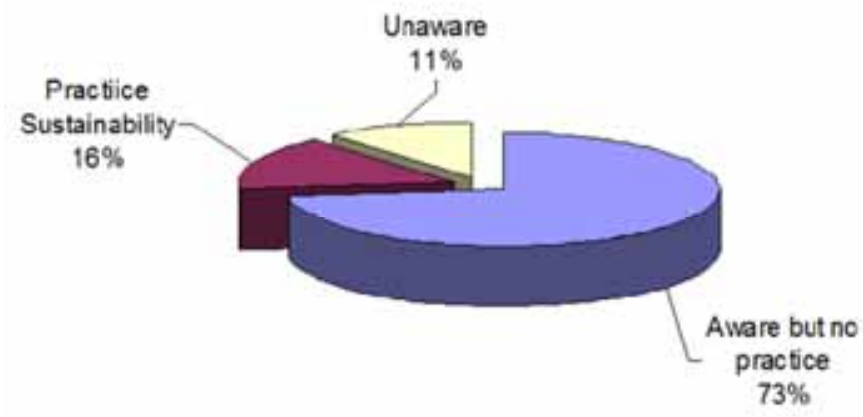

Figure 2. Practice of sustainable housing

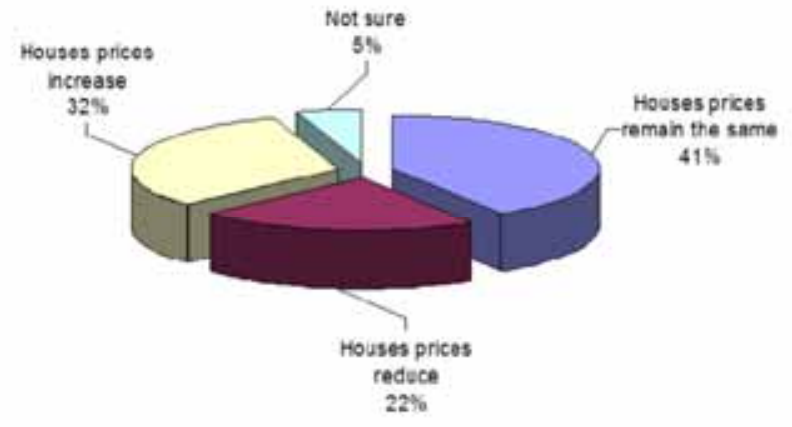

Figure 3. Performance of Housing Market 